\title{
Cellular composition of the cyclic corpus luteum of the cow
}

\author{
J. D. O'Shea, R. J. Rodgers* and M. J. D'Occhioł
}

Department of Veterinary Preclinical Sciences, University of Melbourne, Parkville, Victoria 3052, Australia; *Medical Research Centre, Prince Henry's Hospital, St Kilda Road, Melbourne, Victoria 3004, Australia; and $\dagger$ C.S.I.R.O. Division of Tropical Animal Production, Tropical Cattle Research Centre, Box 5545, Rockhampton Mail Centre, Queensland 4702, Australia

\begin{abstract}
Summary. The cellular composition of CL from 6 cows on $\sim$ Day 12 of the oestrous cycle, after synchronization with cloprostenol, was studied by ultrastructural morphometry. Point-count measurements of volume density (mean \pm s.d.) showed that large luteal cells occupied $40 \cdot 2 \pm 7 \cdot 0 \%$ of the luteal tissue, and small luteal cells $27.7 \pm 6.3 \%$. Of the total of $393.4 \pm 52.0 \times 10^{3}$ cells per $\mathrm{mm}^{3}$ of luteal tissue, large luteal cells made up only $3.5 \%$ and small luteal cells $26 \cdot 7 \%$, a ratio of $1: 7 \cdot 6$. Endothelial cells/pericytes, at $52 \cdot 3 \%$, were the most numerous cell type. The mean volume per large luteal cell was $29.6 \pm 6.3 \times 10^{3} \mu^{3}$, while that of small luteal cells was $2.7 \pm 0.4 \times 10^{3} \mu^{3}$. In spherical form, these volumes would represent mean diameters of $38.4 \mu \mathrm{m}$ and $17.2 \mu \mathrm{m}$ respectively, and are consistent with published measurements on dispersed luteal cells. However, the values for cell numbers are much higher than published values based on luteal tissue dispersion, suggesting that dispersion may result in substantial and possibly selective losses of luteal cells.
\end{abstract}

Keywords: corpus luteum; oestrous cycle; cow; morphometry; luteal cells

\section{Introduction}

Several studies of the function in vitro of enzymically dispersed cells from the corpus luteum (CL) of the cow have identified two functionally distinct cell populations, large and small luteal cells (Ursely \& Leymarie, 1979; Koos \& Hansel, 1981; Chegini et al., 1984; Rodgers et al., 1986; Weber et al., 1987). Criteria for separation of these populations have been based on cell diameter after tissue dispersion, but the cut-off points for the two classes of cell have varied substantially from study to study, making direct comparisons difficult. Chegini et al. (1984) regarded cells $>18 \mu \mathrm{m}$ in diameter as large luteal cells, whereas Weber et al. (1987) used $23 \mu \mathrm{m}$, Koos \& Hansel (1981) $25 \mu \mathrm{m}$ and Rodgers et al. (1986) $26 \mu \mathrm{m}$ as the smallest diameters for these cells.

On the basis of counts of dispersed cell populations from cyclic bovine CL, Hansel et al. (1987) concluded that small luteal cells outnumbered large luteal cells by a ratio of $20: 1-40: 1$, whereas Weber et al. (1987) reported a ratio of only 10-2:1. The relationships of these ratios to the actual numbers of the different cell types in intact luteal tissue are important if realistic estimates of the contributions of the two cell populations to overall luteal function are to be made. In sheep, it has been found that dispersion of luteal tissue may result in selective losses of certain cell types, such that counts of dispersed populations may not accurately reflect the tissue populations (Rodgers $e t$ al., 1984). Hence other forms of estimation of cell numbers are desirable, and morphometry has now provided a clearer picture of cell numbers in sheep (Rodgers et al., 1984; O'Shea et al., 1986; Farin et al., 1986; O'Shea \& McCoy, 1988).

The numbers of cells of different types in luteal tissue are also important in the evaluation of evidence relating to the stability, or interchangeability, of the populations of large and small luteal cells. Alila \& Hansel (1984) have provided evidence, based on the use of monoclonal antibody 
'markers', that small luteal cells of theca origin may enlarge and progressively replace the original, granulosa-derived, large luteal cells in the CL of the cow. The numbers used in support of this argument were based on counts of dispersed cells, showing shifts in the percentages of cells stained by theca-specific and granulosa-specific antibodies as a function of CL age. The interpretation of these findings is critically dependent on the numerical relationships between the dispersed cell populations studied and the populations in the original tissue.

The major purpose of the present study, using ultrastructural morphometry of CL from $\sim$ Day 12 of the oestrous cycle, was to obtain estimates of the numbers and sizes of the large and small luteal cells in intact bovine luteal tissue. Such estimates, providing a basis for comparison with estimates made following tissue dispersion, and with previous studies in sheep, could contribute to the evaluation of existing data on luteal cell function in vitro and on the histogenesis of the CL.

\section{Materials and Methods}

Animals and tissues. Cyclic Shorthorn heifers were maintained under field conditions. Ovulation was synchronized by 2 intramuscular injections of $500 \mu \mathrm{g}$ cloprostenol (Estrumate: Coopers Ltd, North Ryde, New South Wales) 11 days apart (Cooper, 1974). Ovaries were removed following slaughter 14 days after the second injection (assumed to be $\sim$ Day 12 of the oestrous cycle), and CL were carefully dissected out, sliced through their centres to remove any fluid in central cavities, blotted and weighed. A complete thin $(1 \mathrm{~mm})$ slice of luteal tissue was cut from the central surface of each CL, and placed in fixative for electron microscopy. Additional tissue was fixed for light microscopy.

Processing for light and electron microscopy. Tissues for paraffin-wax embedding were fixed in Bouin's fluid, embedded, sectioned at $10 \mu \mathrm{m}$, and stained with haematoxylin and eosin. Tissues for plastic embedding were fixed for $24 \mathrm{~h}$ in a modified FGP fixative (Ito \& Karnovsky, 1968) containing $2.5 \%$ paraformaldehyde, $5 \%$ glutaraldehyde, $0.5 \%$ picric acid and $1.6 \mathrm{~mm}$-calcium chloride in $0.1 \mathrm{M}$-cacodylate buffer, $\mathrm{pH} 7.2$, at room temperature. Blocks of tissue were taken from inner and outer regions of the luteal tissue as described by O'Shea \& McCoy (1988), rinsed in buffer, and post-fixed in 1\% osmium tetroxide in cacodylate buffer for $1 \mathrm{~h}$. Blocks were rinsed, dehydrated in acetone, and embedded in Spurr's embedding medium. Ultrathin sections were stained with uranyl acetate and lead citrate and examined in a Philips EM300 electron microscope. From each of 5 blocks per CL, 5 randomly-selected grid squares of a 200-mesh grid were photographed at a magnification of $\times 1000$, and prints prepared at $\times 2500$.

Morphometric methods. Methods used for measurement of volume density, cell number and cell volume have been reported in detail elsewhere (Rodgers et al., 1984) and are summarized only briefly here. Volume density $\left(\mathbf{P}_{\mathrm{p}}\right)$ was determined by the point-counting method (Weibel, 1979). Forty-two points were counted per micrograph, a total of 1050 points per CL and 6300 points for the $6 \mathrm{CL}$ examined.

Cytoplasmic:nuclear ratios were calculated from the numbers of points on cytoplasm and nuclei for each cell type. Cell identification was based on features reported by Rodgers et al. (1986). Cell numbers per unit volume of tissue $\left(\mathrm{N}_{\mathrm{v}}\right)$ were calculated using the formula

$$
N_{v}=\frac{K}{\beta} \sqrt{\left(\frac{N_{A}^{3}}{P_{p}}\right)} \quad \text { (Formula 2.85, Weibel, 1979), }
$$

where $N_{A}$ is the number of nuclei per unit area of micrograph as measured by image analysis. Size distribution coefficient $K$ was given a value of 1 , indicating uniform size for nuclei of all types. Shape coefficient $\beta$ was given values of 1.382 for nuclei of large and small luteal cells and "other cell types or unidentified", of 1.85 for fibrocytes, and of 2.12 for endothelial cells and pericytes, calculated as described by Rodgers et al. (1984). A linear shrinkage factor of 0.85 was applied in calculating values for cell numbers per unit volume. Tissue specific gravity, and shrinkage during fixation, were calculated by measuring weight, and volume by fluid displacement, of slices of luteal tissue from 4 additional cyclic CL, before and after fixation. Cell volume was calculated by dividing volume density (\%) by the number of cells per unit volume of tissue, and cell diameter was calculated from mean cell volume assuming a spherical shape.

\section{Results}

Luteal weight of the $6 \mathrm{CL}$ studied was $3.8 \pm 0.8 \mathrm{~g}$ (mean \pm s.d.), and volume $3.7 \pm 0.8 \mathrm{~cm}^{3}$. In terms of volume density (Table 1), the combined large and small luteal cells occupied $67.9 \%$ of the luteal tissue, with large luteal cells occupying more of the luteal volume than small luteal cells. The cytoplasmic:nuclear ratio of large luteal cells was $\simeq 4 \cdot 5$-fold greater than that of the small luteal cells (Table 1), with lesser ratios observed for endothelial cells/pericytes and fibrocytes. 
Table 1. Volume density and cytoplasmic:nuclear ratios in the corpus luteum of the cow on Day 12 of the oestrous cycle

\begin{tabular}{lcc}
\hline Component of luteal tissue & $\begin{array}{c}\text { Volume density } \\
(\%)\end{array}$ & $\begin{array}{c}\text { Cytoplasmic:nuclear } \\
\text { ratio }\end{array}$ \\
\hline Endothelial cells and pericytes & $13 \cdot 3 \pm 1 \cdot 7$ & $4 \cdot 6 \pm 0.9$ \\
Large luteal cells & $40 \cdot 2 \pm 7 \cdot 0$ & $44.5 \pm 8 \cdot 9$ \\
Small luteal cells & $27 \cdot 7 \pm 6 \cdot 3$ & $10 \cdot 1 \pm 2 \cdot 8$ \\
Fibrocytes & $6 \cdot 2 \pm 5 \cdot 3$ & $4 \cdot 1 \pm 1 \cdot 8$ \\
Other cell types or unidentified & $1 \cdot 9 \pm 0 \cdot 6$ & \\
Vessel lumen & $1 \cdot 2 \pm 0 \cdot 4$ & \\
Intercellular space & $9 \cdot 5 \pm 3 \cdot 2$ & \\
\hline
\end{tabular}

Values are mean \pm s.d. for $6 \mathrm{CL}$.

Endothelial cells and pericytes represented slightly more than $50 \%$ of all cells within the luteal tissue, while large luteal cells provided $3 \cdot 5 \%$ and small luteal cells $26 \cdot 7 \%$, a ratio of large to small luteal cells of 1:7.6 (Table 2). Total numbers of cells of all types were estimated at $\simeq 1.5 \times 10^{9}$ per CL.

Table 2. Quantitative data on individual cell types in the corpus luteum of the cow on Day 12 of the oestrous cycle

\begin{tabular}{|c|c|c|c|c|}
\hline Cell type & $\begin{array}{c}\text { No. of cells } \\
\text { per } \mathrm{mm}^{3} \times 10^{-3} \\
(\%)\end{array}$ & $\begin{array}{c}\text { No. of cells } \\
\text { per } C L \times 10^{-6}\end{array}$ & $\begin{array}{c}\text { Cell vol. } \\
\left(\mu \mathrm{m}^{3} \times 10^{-3}\right)\end{array}$ & $\begin{array}{c}\text { Cell diam. } \\
(\mu \mathrm{m})\end{array}$ \\
\hline $\begin{array}{l}\text { Endothelial cells } \\
\text { and pericytes }\end{array}$ & $\begin{array}{c}205 \cdot 4 \pm 42 \cdot 5 \\
(52 \cdot 3)\end{array}$ & $779 \cdot 8 \pm 331 \cdot 5$ & $0 \cdot 67 \pm 0 \cdot 15$ & $10 \cdot 8$ \\
\hline Large luteal cells & $\frac{13.8 \pm}{(3.5)}$ & $51 \cdot 5 \pm 15 \cdot 4$ & $29 \cdot 55 \pm 6 \cdot 25$ & $38 \cdot 4$ \\
\hline Small luteal cells & $\begin{array}{l}105 \cdot 2 \pm 22 \cdot 1 \\
\quad(26 \cdot 7)\end{array}$ & $392 \cdot 4 \pm 135 \cdot 1$ & $2.65 \pm 0.35$ & 17.2 \\
\hline Fibrocytes & $\begin{array}{l}39 \cdot 4 \pm 32 \cdot 3 \\
(10 \cdot 0)\end{array}$ & $147 \cdot 5 \pm 128.9$ & $1.70 \pm 1.06$ & 14.8 \\
\hline $\begin{array}{l}\text { Other cell types } \\
\text { or unidentified }\end{array}$ & $\begin{array}{c}29 \cdot 6 \pm 25 \cdot 5 \\
(7 \cdot 5)\end{array}$ & $106.4 \pm 103.7$ & & \\
\hline Total & $\begin{array}{l}393 \cdot 4 \pm 52 \cdot 0 \\
\quad(100)\end{array}$ & $1477 \cdot 6 \pm 513 \cdot 1$ & & \\
\hline
\end{tabular}

Values are mean \pm s.d. for $6 \mathrm{CL}$.

* Diameter (mean) calculated from cell volume if cells assumed to be spherical.

The mean volume per individual large luteal cell, at $30 \times 10^{3} \mu \mathrm{m}^{3}$, was 11 times that per individual small luteal cell (Table 2). These volumes, converted to a spherical shape, provided estimates of mean diameter of $38.4 \mu \mathrm{m}$ and $17 \cdot 2 \mu \mathrm{m}$ for the large and small luteal cells (Table 2).

\section{Discussion}

The present point-count data on volume density, showing a combined value of almost $70 \%$ for bovine large and small luteal cells at mid-cycle, accord closely with values obtained previously by Parry et al. (1980). They are, however, higher than estimates obtained for sheep in which values were closer to $50 \%$ (O'Shea et al., 1986). While some real inter-species variation may exist it is likely that a major reason for this difference lies in the method of tissue fixation. Perfusion fixation, as used in sheep, resulted in a combined value of $\simeq 28 \%$ for vascular lumina and intercellular 
spaces. The equivalent value of $\simeq 11 \%$ in the present study, using immersion fixation, could largely account for the apparent between-species difference in luteal cell volume density.

Cell numbers have not previously been estimated by morphometry in the cow, but the values obtained here on a per-unit-volume basis are similar to those obtained previously for mid-cycle sheep (O'Shea et al., 1986). While the present estimate for large luteal cells is a little lower than that for sheep, both in absolute and percentage terms, the individual large luteal cells appeared to be substantially larger in the cow. However, the present morphometric estimates of cell diameter accord closely with those of Ursely \& Leymarie (1979), who reported mean diameters of $37 \mu \mathrm{m}$ and $18 \mu \mathrm{m}$ for dispersed large and small luteal cells of cows.

While there is some evidence that the CL formed after ovulation synchronized by prostaglandin analogues in cows may not be identical to CL formed during natural cycles, at least in Bos indicus cattle (Hardin \& Randell, 1982; Hansen et al., 1987), comparisons with data from Parry et al. (1980) and Ursely \& Leymarie (1979) for naturally cyclic cows show close similarities with the present observations. Therefore, although caution is necessary, some comparisons between the present morphometric data and findings from studies using dissociated cell populations may be of value.

With regard to total cell numbers obtained following tissue dispersion, Hansel et al. (1987) obtained estimates of $1.13 \times 10^{6}$ large luteal cells and $19 \cdot 3 \times 10^{6}$ small luteal cells per gram of tissue on Days 10-12 of the oestrous cycle (compared with $13.6 \times 10^{6}$ and $103.3 \times 10^{6}$ respectively in the present study). If mean volumes for cells in these two populations are calculated using the mean diameters ( $37 \mu \mathrm{m}$ for large luteal cells, $18 \mu \mathrm{m}$ for small luteal cells) provided by Ursely \& Leymarie (1979), the combined population of large and small luteal cells obtained by Hansel et al. (1987) would account for less than $10 \%$ of the volume in $1 \mathrm{~g}$ of luteal tissue. This compares with point-count estimates of $70 \%$ by Parry et al. (1980), and 67.9\% in the present study, suggesting heavy losses of cells during dispersion. Even lower values of cell dispersion recovery $\left(0.017 \times 10^{6}\right.$ large and $0.173 \times 10^{6}$ small luteal cells/g) were obtained by Weber et al. (1987) from bovine CL on Day 14 of the oestrous cycle.

In terms of the proportions of small to large luteal cells, the present estimate of $7 \cdot 6: 1$ is a little lower than that of 10.2:1 obtained by Weber et al. (1987) from dispersed luteal tissue on Day 14, and substantially lower than that of 20:1-40:1 reported by Hansel et al. (1987) for cyclic cows. The extent of these discrepancies suggests that the losses occurring during luteal tissue dispersion may be selective, with a preferential loss of large luteal cells.

If selective losses of large luteal cells did occur in the studies of Alila \& Hansel (1984) and Hansel et al. (1987), the percentages of cells staining with the two antibodies used may not have accurately reflected the percentages in the original tissues. Hence granulosa-derived large luteal cells could have been systematically underestimated. These considerations, together with the observation of Alila \& Hansel (1984) that a progressively increasing number of large luteal cells bound neither the theca-specific nor the granulosa-specific antibody, suggest that it may be premature to conclude that the granulosa-derived large luteal cells "disappear during early pregnancy" (Alila \& Hansel, 1984). In fact, none of the available data are really inconsistent with the idea that some, or even all, of the granulosa-derived cells persist until the onset of luteal regression.

In conclusion, the present morphometric results indicate that the cellular composition of the cyclic CL of the cow is similar to that of the ewe. They further suggest that tissue dispersion can result in substantial and possibly selective losses of cells, so that cell populations obtained by dispersion may not accurately represent the populations in intact tissues. These findings have important implications in interpretation of the cell kinetics of the bovine CL.

We thank Mrs Karen McCoy and Mr Tony Weatherly for excellent technical assistance, and the National Health and Medical Research Council of Australia and the J. S. Davies Bequest for financial assistance. 


\section{References}

Alila, H.W. \& Hansel, W. (1984) Origin of different cell types in the bovine corpus luteum as characterized by specific monoclonal antibodies. Biol. Reprod. 31, $1015-1025$.

Chegini, N., Ramani, N. \& Rao, C.V. (1984) Morphological and biochemical characterization of small and large bovine luteal cells during pregnancy. Molec. cell. Endocrin. 37, 89-102.

Cooper, M.J. (1974) Control of oestrous cycles of heifers with a synthetic prostaglandin analogue. Vet. Rec. 95, 200-203.

Farin, C.E., Moeller, C.L., Sawyer, H.R., Gamboni, F. \& Niswender, G.D. (1986) Morphometric analysis of cell types in the ovine corpus luteum throughout the estrous cycle. Biol. Reprod. 35, 1299-1308.

Hansel, W., Alila, H.W., Dowd, J.P. \& Yang, Z. (1987) Control of steroidogenesis in small and large bovine luteal cells. Aust. J. biol. Sci. 40, 331-347.

Hansen, T.R., Randel, R.D., Segerson, E.C., Rutter, I.M. \& Harms, P.G. (1987) Corpus luteum function following spontaneous or prostaglandin-induced estrus in Brahman cows and heifers. J. Anim. Sci. 65, 524-533.

Hardin, D.R. \& Randel, R.D. (1982) The effect of cloprostenol and cloprostenol + HCG on corpora lutea and serum progesterone in Brahman cows. Theriogenology 17, 669-675.

Ito, S. \& Karnovsky, M. (1968) Formaldehyde-glutaraldehyde fixatives containing trinitro compounds. $J$. Cell Biol. 39, 168A-169A.

Koos, R.D. \& Hansel, W. (1981) The large and small cells of the bovine corpus luteum: ultrastructural and functional differences. In Dynamics of Ovarian
Function, pp. 197-203. Eds N. B. Schwartz \& M. Hunzicker-Dunn. Raven Press, New York.

O'Shea, J.D. \& McCoy, K. (1988) Weight, composition, mitosis, cell death and content of progesterone and DNA in the corpus luteum of pregnancy in the ewe. J. Reprod. Fert. 83, 107-117.

O'Shea, J.D., Rodgers, R.J. \& Wright, P.J. (1986) Cellular composition of the sheep corpus luteum in the mid- and late-luteal phases of the oestrous cycle. $J$. Reprod. Fert. 76, 685-691.

Parry, D.M., Willcox, D.L. \& Thorburn, G.D. (1980) Ultrastructural and cytochemical study of the bovine corpus luteum. J. Reprod. Fert. 60, 349-357.

Rodgers, R.J., O'Shea, J.D. \& Bruce, N.W. (1984) Morphometric analysis of the cellular composition of the ovine corpus luteum. J. Anat. 138, 757-769.

Rodgers, R.J., Rodgers, H.F., Waterman, M.R. \& Simpson, E.R. (1986) Immunolocalization of cholesterol side-chain-cleavage cytochrome P-450 and ultrastructural studies of bovine corpora lutea. $J$. Reprod. Fert. 78, 639-652.

Ursely, J. \& Leymarie, P. (1979) Varying response to luteinizing hormone of two luteal cell types isolated from bovine corpus luteum. J. Endocr. 83, 303-310.

Weber, D.M., Fields, P.A., Romrell, L.J., Tumwasorn, S., Ball, B.A., Drost, M. \& Fields, M.J. (1987) Functional differences between small and large luteal cells of the late-pregnant vs. non-pregnant cow. Biol. Reprod. 37, 685-697.

Weibel, F.R. (1979) Stereological Methods, Vol. 1. Practical Methods for Biological Morphometry. Academic Press, London.

Received 10 June 1988 